\title{
World English, Euro-English, Nordic English?
}

\author{
TOM McARTHUR
}

\author{
A discussion of the kinds of English emerging in the world at \\ large and in the European Union
}

[The opening address to the annual conference of the Finnish-British Societies, in collaboration with the British Embassy and the English Department of the University of Helsinki, at the British Ambassador's residence, 28 Sep 2002.]

IN RECENT YEARS, the world's Anglophone media, in the company of a range of other observers, have routinely been calling English 'the world's lingua franca'. As a result, the phrase is now something of a cliché. We're all 'global' now, and need to use the first truly universal language, whether we are business people, politicians, teachers, tourists, or terrorists.

Manifestly the world language is English, but if it hadn't been English then another language would presumably have taken on the job, because we need such a language. If so, it may be worthwhile to make a certain distinction right away: that is, between English in its own right and English in its global role. That is, some issues primarily concern us because English is the way it is (strange spelling, irregular verbs, kinds of rhythm and stress, and so forth), and other issues concern us not because of how English is but because of what it makes possible, through for example its key role in aviation, shipping, the media, the United Nations, NATO, the European Union, and so on. So, if you want to be in world aviation, you learn your irregular verbs.

If we next ask about alternatives to English, two further points emerge. First: Given the nature of contemporary international society, any alternative language to English would probably also be European in origin, probably Spanish or French. If either of these was the lingua franca, it would offer Europe at large much the same benefits as English. This is because, whatever differences there are among European languages, these languages belong in the same cultural matrix, which encompasses three powerful blended traditions: the GrecoRoman, the Christian, and a scientific-cumtechnological revolution. Second: If circumstances had been different and European languages had not been predominant internationally in recent centuries, then a language from another cultural matrix would probably have prevailed, and in that situation life would have been harder for all Europeans.

Imagine, for example, if the world's lingua franca had been Arabic or Chinese. We Europeans would then have had to deal with a markedly different writing system, as opposed to the present situation in which the rest of the world has had to master an alphabet and orthography broadly shared by Central and Western Europe and not too unlike those in Eastern Europe, but generally very different

TOM MCARTHUR was born in Glasgow in 1938. A graduate of Glasgow and Edinburgh universities, he has been an officer-instructor in the British Army, Head of English at the Cathedral School, Bombay, organizer of courses for overseas students at the University of Edinburgh, associate professor of English at the Université du Québec, and Deputy Director of the Dictionary Research Centre at the University of Exeter. His publications include the 'Longman Lexicon of Contemporary English', 'A Foundation Course for Language Teachers',

'Languages of Scotland', 'Worlds of Reference', 'The Oxford Companion to the English Language,' 'The English Languages', and 'The Oxford Guide to World English'. 
from what has gone on in their own cultural matrices. So there is a serious sense in which Europeans would be fortunate if any major European language became the global lingua franca.

Yet, even if many things were radically different, some would be much the same as at the moment, which brings me to my next point, that people's attitudes to the predominance of a particular language seem to range along much the same social and emotional continuum: They can be (generally or at different times) positive, negative, calm, angry, neutral, mixed or unconcerned, but in the last analysis they are pragmatic. Indeed, the crucial response of most people to a language of wider use appears to relate to three questions: First, 'Will knowing and using this language make my life easier and/or richer?' (in any sense of the word rich). Second, 'Will my children need this language to get on in the world?' And third: 'If so, how soon should they start acquiring it?' And the conclusion they reach in answer to that last question, in my experience, is: 'As soon as possible.' Cultural interest and linguistic curiosity are all very well, but they are minority pursuits. Pragmatism tends to win the day.

There is another point worth making here: Although the world's key language could have been other than English, potential global lingua francas are not in fact thick on the ground. They need to be in really wide use, which in fact rules out Spanish, Arabic, and Chinese: they are certainly big, but they are not evenly distributed. In addition, a world lingua franca cannot be legislated for, because the world has never had a mechanism for such legislation; instead, such a language arises out of historical circumstance. Furthermore, a world lingua franca cannot be invented and then spread by people of good will, however dedicated they may be, as the fate of Ludwig Zamenhof's Esperanto has shown. Indeed, it cannot even be achieved by simplifying a given world language like English itself, as was shown by the fate of Ogden and Richards' Basic English between the 1920s and 1940s, despite initial successes. Although nowadays English is graded for learners in various ways, they still have to aim at acquiring as close to the whole thing as they can get. There are no magic shortcuts.

English occupies its current position because it was, as it were, in training for a long time: indeed, for more than 250 years, ever since it began to spread worldwide in the 18th century. Yet, although English did not suddenly become predominant in the 20th century, 1945 was a most significant date. By mid-century, the British were still prominent in the world, although their empire was about to come to an end, and the Americans were more potent internationally than ever before, so that their version of English was increasingly significant. At the close of what the British usually call the Second World War and what the Americans call World War II, German was removed as a competitor for world linguistic domination and Japanese returned to the confines of Japan, where it has largely stayed ever since. In a rather similar way, in the early 1990s, the collapse of the Soviet Union and international communism removed Russian from the competition, although its global prospects had in fact been in decline for several decades. All of which demonstrates the linguistic relevance of such matters as war, politics, economics, and opportunity.

My next points relate to number of users, their distribution, and the major functions of a language. In terms of numbers of users, English is not the largest language in the world. That honour goes to Chinese. In terms of distribution, many large languages are widely distributed, as for example Hindi and French, but they are not as widely distributed as English. In functional terms, many major languages have had (and continue to have) distinct, even unique, world roles, such as Arabic as the primary medium of Islam and Italian as a key performer in musicology. English does not interfere with them in any way, but has a whole raft of such roles of its own, notably in the sciences, education, business, travel, and transport. And it is pre-eminently the language of the world's media. Indeed, even where national media do not print or broadcast in English, they still use it behind the scenes as their key channel for gathering and sifting world news and views.

Even if English were not a European language, it would remain a language of prime concern in Europe. This is an intriguing issue for me as a British national, because I am well aware that English is an off-shore European language, and that in both mainland European and UK terms it is not really truly European, because Europe is over $(\mathrm{t})$ here, on the far side of the Channel. Furthermore, much of the impact of English in Europe in recent decades 
has been not from the UK but the US, which is manifestly an influence from beyond Europe. Let me put it this way: If people in mainland Europe had been betting on a future European common language, say, 200 to 100 years ago, the odds in favour of French or German would have been very good and English would have been a rank outsider

\section{The English language complex}

It needed all of 250 years for English to acquire current prominence in terms of its two major standard varieties, UK and US, or as I like to think of them, the two main strands of a single World Standard English, in which the US strand has predominated over the last thirty years or so. The same process also made it highly varied, to such an extent that when I was working on The Oxford Guide to World English (published in May this year), I felt the need to go beyond the basic terms 'English' and 'English language' to the idea of an 'English language complex'.

The idea of such a complex helps one cover, but also get beyond, such issues as 'English', the name of a European people, 'English', the sole language of that people, 'English' the language of places around the world influenced by that people, and 'English' the world's lingua franca. The idea of a complex also helps me handle the term 'English' as shorthand for both 'Standard English' and 'English literature', and to manage the occurrence of 'English' with innumerable attributives: 'British English', 'American English', 'Irish English', 'Indian English', 'New York English', 'London English', 'Oxford English', and of course 'Euro-English', maybe 'Nordic English', and maybe even 'Finnish English'. There seems in principle to be no upper limit to the number of such labels and the realities they represent.

Such labels also often have a paradoxical element. 'Scottish English', for example, is like a contradiction in terms; 'English English' (as favoured very reasonably by the English sociolinguist Peter Trudgill) is nonetheless like something out of Alice in Wonderland; and 'American English' should mean the English of the Americas but in fact relates only to the US. 'North American English' covers more of the Americas, but not much more, since it adds only Canada.

The phrase 'English language complex' is generous enough to handle such issues. It helps, for example, when one discusses the situation of English in Scotland, in which there is a minority 'more English' way of speaking alongside a majority 'more Scottish' way of speaking - whose full traditional form is known as 'Scots'. Some people consider that Scots is a dialect of English, while others regard it as a distinct Germanic language, as close to English as, say, Norwegian is to Danish. The Aberdeen University scholar Derrick McClure sees English and Scots as distinct entities within what he calls 'Insular Germanic', which he contrasts with 'Continental Germanic', which of course includes Dutch and German. In effect, as he sees it, Scots is a Nordic language.

Scots is my mother tongue, and was certainly my mother's tongue: she spoke Scots and wrote English, and I grew up speaking a mix of Scots and Scottish English and writing English. Scots is not the language in which I function professionally; it long ago lost its upper social registers, and it would be strange in Scotland, as elsewhere, if I tried to use it in a talk like this. Sae Ah'm no daein it, an mibbe Ah cannae dae it, no consístently ('So I'm not doing it, and maybe I can't do it, not consistently'). In linguistic terms, a paradoxical case can be made for Scots as both a distinct language and a kind of English, but no case can be made for English being a kind of Scots. There's power for you. I am however pleased to say that Scots is now recognised as a minority language of the European Union.

Another illustration of the useful flexibility of the phrase 'language complex' is English in the Caribbean, where the language co-exists with a majority usage commonly known as 'Creole'. However, the relationship between Caribbean English and Creole is emotive and can be divisive, but linguists insist that, whatever Creole may be, English cannot be discussed in the Caribbean without bringing Creole in. The nature and use of Caribbean Creole is therefore necessarily part of the discussion of Caribbean English and therefore of English as a world phenomenon. Creole is part of the complex, in which there is a continuum from what is 'conventionally' English in world terms through what may or may not be 'proper' English to what is manifestly not English, yet cooccurs with it every day.

A third relationship will demonstrate the outer limits, as it were, of this vast complex. This time it is the use of English alongside Malay in Malaysia, Indonesia, Brunei, and Singapore. 
A great deal of English can also be found inside present-day Malay, because the government has officially used English as the primary source of adopted and adapted borrowings, in order to enlarge the lexis of Malay (or Bahasa Malaysia as it is officially known). Malay and English in fact interact all the time, producing a hybrid known as both 'Malenglish' and 'Manglish'. An example from a TV serial:

A: Thanks, Ita, for house-sitting for me.

B: No problem. Apartment kau lebih cantik darpada apartment apu.

Anyway, it's all yours again.

['...Your apartment is much more beautiful than mine.']

[from Andrew Preshous, 'Where you going ah?', in English Today 65 [17:1], Jan 01, Cambridge University Press]

Malay is only one of a multitude of languages with which kinds of English ('Englishes') mix on every continent. These languages are on the edge of the complex, as it were, mixing, lending, borrowing, co-existing, and co-developing. It is often therefore hard to say where English stops and other entities begin, and in such a world the BBC and CNN offer kinds of reassurance, serving as virtual global gold standards. I have needed a term, however, for what has been happening with Malay and other languages, and the one I decided on some years ago is 'Anglo-hybrid'. There are more Anglohybrids in the world than one can easily count.

\section{Euro-English}

So far my examples have been Scotland, the Caribbean, and the nations that use Malay. In all such regions, English has been established for centuries, but, in some parts of the world, it is a more recent acquisition, and mainland Europe is one of them. It should, I suggest, be no surprise if we see comparable things to what I have just described emerging in continental Europe as a whole, in the European Union, in regions of the EU, and in individual countries. Classic cases are of course franglais and Deutschlish. In more recent years, and at a higher level, another term has arisen, and it has been equally negatively-skewed. The term 'Euro-English' has often been used to mean 'bad English perpetrated in Brussels', where it has been associated with an even more hybridized and dubious phenomenon known as Eurospeak.

Last week I read with interest the autumn
2001 issue of the Finn-Brits Magazine. In that issue is an article by Emma Wagner of the European Commission, who spoke at last year's conference. Her title was 'Euro-English: A problem or a solution?', and in the article she expressed concern about two issues: first, that Euro-English is, or risks becoming, a language of the elite; second, that the usage of the European Commission is replete with 'Eurospeak, Eurowaffle and plain bad English'. Certainly the issue of elitism is important. I have often felt the need to compare the EU with India, a vast multilingual nation for which English, with its various kinds of official status, is known especially as India's 'link language' and 'window on the world'. As such it is inevitably the language of an elite, however defined, and for this reason many impoverished people detest it mainly because they do not have access to it. Equally certainly, jargon is an impediment to clear and efficient communication.

For me, the issue in Brussels and the EU at large is the growing centrality of English, regardless of how well and/or how badly it is used. Jargon is no respecter of boundaries. But, crucially, Emma Wagner's article ties in with my experience as editor of English Today, in which we have published a range of papers on English in Europe. From these and other sources, it is clear that Euro-English (for good or for ill, or both) is now an established term, and notably the Euro- element has become shorthand for the European Union rather than for Europe as a whole.

We live in a time when the classic divisions describing users of English are becoming ever harder to maintain. We all know the three categories native users, second-language users, and foreign-language users. Once they were fairly clear: the first were born to English, the second had it thrust upon them in colonial times, and the third was everybody else who knew any English. Now, however, they have very fuzzy edges. Many native users have low opinions of the English of other native users, at home or abroad; many second-language users are manifestly more fluent in some aspects of the language than many natives, especially in professional activities; and many foreign users know and use the language better than many native- and second-language users, the outcome of a learning process that began in childhood, The distinction 'second' and 'foreign' seems therefore much less valuable than it may once have been. 
It has become hard to maintain such distinctions among highly educated and experienced users of the language, wherever they may be. A century ago this state of affairs might have been measured in a few millions worldwide at most, but now it must be discussed in terms of tens of millions of people who use the language regularly, even routinely. And, I would argue, the areas in which this reality has become particularly real are the Netherlands and Scandinavia, after which come Germany and Finland inside the EU and Switzerland just outside. Consider for example the language policies and use of the three companies Royal Dutch Shell, ABB, and Nokia.

There is an area of risk here, which many people are increasingly aware of. I have surprised colleagues in the Netherlands and Scandinavia by raising with them a risk that I think of as the 'Scotlandization' of northern Europe: that is, that the professional and scholarly levels of such languages as Dutch and Swedish are giving way massively to English, notably in business, the media, publishing, and higher education, much as happened with Scots around 1700. A second, less direct influence is the massive absorption of Anglicisms into the mother tongue. And a third is Anglo-hybridization, as in my Malay example.

A Dutch colleague, Reinier Salverda, Professor of Dutch at University College London, tells me that in the near future all Dutch people will be bilingual. The same process seems to be under way in Denmark, Norway, and Sweden, and many Finns are already trilingual in Finnish, Swedish and English, with this language trio in that order on many signs in and around Helsinki. The linguistic background of most Finns is very distinct, of course, but Nokia's policy of using English as its language of business is a thought-provoking straw in the wind.

On August 13, 2001, an article appeared in the US publication Business Week with the title
'The Great English Divide'. Written by Stephen Baker and Inka Resch in Paris, it starts off as follows:

In Europe, speaking the lingua franca separates the haves from the have-nots.... English is becoming the binding agent of a continent, linking Finns to French and Portuguese as they move towards political and economic unification.... 'If I want to speak to a French person, I have to speak in English,' says Ivo Rowekamp, an 11-year-old in Heidelberg, Germany.

Ah yes, but just what kind of English is it, this novel medium that even the French are using (apart from bad style in Brussels)? In a recent issue of English Today, Barbara Seidlhofer of the University of Vienna has been moving towards an answer to this question. She notes:

If 'Euro-English' is indeed an emerging variety as a European lingua franca, then it should be possible to describe it systematically, and eventually also to provide a codification which would allow it to be captured in dictionaries and grammars and to be taught, with appropriate teaching materials to support this teaching (in "Towards making "Euro-English" a linguistic reality', ET68, Oct 01).

That is also quite a thought, and the kinds of research that she is interested in are beginning to emerge, notably in the project with which she is concerned, the Vienna-Oxford ELF Corpus, where ELF stands for 'English as a lingua franca'. It is early days, but we may yet see course guides, grammars, and dictionaries dealing in how mainland Europeans at large and the citizens of such countries as Finland and France in particular have been adding their phonologies and idioms to the world's and Europe's - lingua franca. Exploring EuroEnglish is a potentially vast project, and we should welcome it. But probably it should also carry a warning, such as 'Caution: Handle with care.' Printed of course in every EU language. 